\title{
RESPONSE SURFACE METHODOLOGY OF PRESSURIZED LIQUID WATER EXTRACTION OF CURCUMIN FROM CURCUMA DOMESTICA VAL
}

\author{
M.E. Yulianto ${ }^{1}$, V.Paramita ${ }^{1}$, I. Hartati ${ }^{2, *}$ and R. Amalia ${ }^{1}$ \\ ${ }^{1}$ Diploma III Programme of Chemical Engineering, Diponegoro University, Indonesia \\ ${ }^{2}$ Chemical Engineering Department, Faculty of Engineering, \\ Wahid Hasyim University, Indonesia \\ *E-mail: hartatiprasetyo@gmail.com
}

\begin{abstract}
Curcumin, an active compounds found in Curcuma domestica Val, exhibits many pharmacological effects. Due to its numerous benefits, pressurized liquid water extraction is gaining many interests from researchers. Response Surface Methodology applied in the optimization study of the pressurized liquid water extraction of curcumin from Curcuma domestica Val. Central Composite Design was applied in the design of this research. The parameter process studied were temperature $\left(130-150^{\circ} \mathrm{C}\right)$, time (20-40 minutes) and reaction volume (4-6.2 L). The solid-liquid ratio was fixed at a ratio of 1:10, ad the pressure was fixed of 2 bar. Response surface of the pressurized liquid water extraction of curcumin was expressed by a second-order polynomial. The research showed that the model we adequate to predict the pressurized liquid water extraction of curcumin in the range of variables studied in this research. The research showed that temperature was the most influencing variable for pressurized liquid water extraction of curcumin from Curcuma domestica Val. The optimal value of the pressurized liquid water extraction of curcumin was obtained by solving the second-order polynomial regression equation. The curcumin pressurized liquid water extraction was optimum at an extraction temperature of $156.81^{\circ}$, extraction time of 46.81 minutes and solvent volume of $6.95 \mathrm{~L}$.
\end{abstract}

Keywords: Currcuma domestic Val, PLE, extraction, curcumin, RSM

(C) RASĀYAN. All rights reserved

\section{INTRODUCTION}

At present, nearly up to $40 \%$ among the thousands of worldwide used pharmaceutical products were occupied by plant medicine, which mainly comes from plant extraction ${ }^{1}$. Over the exploration for the potential candidate for pharmaceuticals, extraction and separation process was the most important step in the drug development. There are numerous methods applied for extracting phytochemicals from plant materials. The methods are including soxhlet extraction, conventional solvent extraction, steam distillation, maceration, and sublimation, etc. While such methods are reported having several advantages, they are difficult to be scaled up to commercial through due to the problems associated with safety, low extraction efficiency, longer operation time, cost-effectiveness, and completely removing and recovering the toxic organic solvents residues from both the extracts and materials spent plant. ${ }^{1-2}$

Nowadays, many new technologies and methods are introduced to the extraction and separation of phytochemicals. Among those new technologies, the application of pressurized liquid water as the medium of extraction has to gain much interest from researchers. Compared to the traditional extraction techniques, pressurized liquid water extraction offers several advantages including shorter extraction time, lower cost of the extracting solvent, higher quality of the extraction, selective and environment-friendly. ${ }^{1-3}$ Pressurized liquid water is refers to water at temperature between 100 and $374^{\circ} \mathrm{C}$ and at a pressure which is high enough to maintain the liquid state (below the critical pressure of $22 \mathrm{MPa}$ ). ${ }^{2}$ Water in the subcritical region has unique properties including the low of the dielectric constant and the high polarity due to the breakdown of the intermolecular hydrogen bonds of water. ${ }^{4}$ The high temperature and pressure of the pressurized liquid water also produce high diffusion rates which promote the high efficiency of the extraction process. ${ }^{1}$

Rasayan J. Chem., 11(4), 1564-1571(2018) http://dx.doi.org/10.31788/RJC.2018.1141990

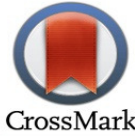


Hot compressed water extraction has been applied in the extraction of bioactive compounds, essential oil, phenol, anthraquinones, cellulose, and lignin..$^{1-4}$ In this paper, pressurized liquid water is applied for the separation of curcumin from Curcuma domestica Val. Curcuminoid, which comprised of three major components i.e curcumin, dimethyoxycurcumin and bis demethoxycurcumin, is the main dietary photochemical found in the rhizomes of Curcuma domestica Val. Curcumin is the main coloring substance in Curcuma domestica Val. The curcuminoid content determined the value of Curcuma domestica Val products. Curcumin is reported as the most active curcuminoid. It has been shown to possess a multitude of beneficial effects in the treatment of cancers, prevents and treats stomach ulcers, cardiovascular disease, and inflammation. Curcumin is also reported possessed numerous pharmacological activity including, antihepatotoxicity, cholagogic, and anti-tumor effect. Curcumin is widely used to color many foods since it is listed for use in various products such as dairy products, protein products, fats and oil products, fruit and vegetable products, confectionery, bakery wares, meat and meat products, fish and fish products, cereal products, and eggs and eggs products.,

The optimization of the pressurized liquid water of curcumin from Curcuma domestica Val was studied in this research and presented in this paper.

\section{Materials}

\section{EXPERIMENTAL}

Curcuma domestica Val was supplied by a local supplier from Semarang, Central Java, Indonesia. It was dried, ground and used as raw material for the pressurized liquid water extraction process.

\section{Pressurized Liquid Water Extraction}

The experiments are designed by using Central Composite Design. The independent variables of pressurized liquid water extraction of curcumin were $\mathrm{X}_{1}, \mathrm{X}_{2}$, and $\mathrm{X}_{3}$ temperature, extraction time and solvent volume, respectively. Each variable to be optimized was coded at five levels: $-\alpha,-1,0,+1$ and + $\alpha$. This gives a range of these variables of pressurized liquid water extraction of curcumin (Table-1). The experiments are designed was tabulated in Table- 2 .

Table-1: Central Composite Design for Optimization of Curcumin Pressurized Liquid Water Extraction

\begin{tabular}{c|c|c|c|c|c}
\hline Independent variables & \multicolumn{5}{|c}{ Coded variable levels } \\
\cline { 2 - 6 } & $\mathrm{A}$ & -1 & 0 & +1 & $\alpha$ \\
\hline Temperature $\left({ }^{\circ} \mathrm{C}\right)$ & 123.18 & 130.00 & 140.00 & 150.00 & 156.82 \\
\hline Time (Minutes) & 13.18 & 20 & 30 & 40 & 46.82 \\
\hline Solvent Volume (L) & 3.25 & 4 & 5.1 & 6.2 & 6.96 \\
\hline
\end{tabular}

The pressurized liquid water extraction of curcumin was started by weighing $428 \mathrm{~g}$ of ground Curcuma domestica Val. It was then loaded into the extraction cell. The distilled water of a certain volume was added into the cell. After the cell was securely covered with a lid of stainless steel, nitrogen gas was then passed through to purge air. The hot compressed water extractions were carried out at a temperature of $130-150^{\circ} \mathrm{C}$, and extraction time of 20-40 minutes at a fixed pressure of 2 bar. Once the extraction process was completed, the extraction mixture was transferred into the cooling cell. Samples were taken and been analyzed its curcumin content by using UV Vis spectrophotometer.

Table-2: The Experiments Design of Optimization of Pressurized Liquid Water Extraction of Curcumin

\begin{tabular}{c|c|c}
\hline Temperature $\left({ }^{\circ} \mathrm{C}\right)$ & Time (Minutes) & $\begin{array}{c}\text { Solvent Volume } \\
(\text { Liter })\end{array}$ \\
\hline 130.00 & 20.00 & 4.00 \\
\hline 130.00 & 20.00 & 6.20 \\
\hline 130.00 & 40.00 & 4.00 \\
\hline 130.00 & 40.00 & 6.20 \\
\hline
\end{tabular}


RASĀYAN J. Chem.

Vol. 11 | No. 4 |1564 - 1571| October - December | 2018

\begin{tabular}{l|l|l}
\hline 150.00 & 20.00 & 4.00 \\
\hline 150.00 & 20.00 & 6.20 \\
\hline 150.00 & 40.00 & 4.00 \\
\hline 150.00 & 40.00 & 6.20 \\
\hline 123.18 & 30.00 & 5.10 \\
\hline 156.82 & 30.00 & 5.10 \\
\hline 140.00 & 13.18 & 5.10 \\
\hline 140.00 & 46.82 & 5.10 \\
\hline 140.00 & 30.00 & 3.25 \\
\hline 140.00 & 30.00 & 6.95 \\
\hline 140.00 & 30.00 & 5.10 \\
\hline 140.00 & 30.00 & 5.10 \\
\hline
\end{tabular}

\section{Curcumin Determination}

The pressurized liquid water extract solution was diluted up to $25 \mathrm{ml}$ by alcohol (95\%) in a ratio of 1:12.5 of extract:alcohol. The solution was subjected to a SHIMADZU UV/Visible double beam spectrophotometer and the absorbances were recorded at $425 \mathrm{~nm}$. The spectral width and the accuracy of the wavelength of the UV/Visible double beam spectrophotometer were $2 \mathrm{~mm}$ and $0.5 \mathrm{~mm}$, respectively. The duplo absorbance measurement of the solution was done by using a pair of $10 \mathrm{~mm}$ of a matched quartz cell. The percentage of curcumin content was found out from the calibration curve of standard curcumin.

\section{RESULTS AND DISCUSSION}

Many types of research have used Response surface methodology (RSM) in the optimization of the various process including in the optimization of acid hydrolysis of grasses ${ }^{7}$, rice husk lignin extraction ${ }^{8}$, fiber reinforcement ${ }^{9}$, and biodiesel production ${ }^{10}$. RSM is an empirical statistical technique employed for multiple regressions analysis. It used multivariable-quantitative data to solve multivariable equation simultaneously. In this research, a central composite design has employed the response, namely the curcumin concentration. The independent variables of pressurized liquid water extraction of curcumin were $\mathrm{X}_{1}, \mathrm{X}_{2}$, and $\mathrm{X}_{3}$ temperature $\left({ }^{\circ} \mathrm{C}\right)$, extraction time (minutes), and solvent volume $(\mathrm{L})$, respectively. The data obtained by carrying out the experiment according to central composite design were analyzed by Statistica 8 . The data obtained were tabulated on Table- 3 .

Table-3: The Tabulated Data of the Pressurized Liquid Water Extraction of Curcumin

\begin{tabular}{c|c|c|c}
\hline Temperature $\left({ }^{\circ} \mathrm{C}\right)$ & Time (Minutes) & Solvent Volume (Liter) & Curcumin Concentration (\% w) \\
\hline 130.00 & 20.00 & 4.00 & 18.01 \\
\hline 130.00 & 20.00 & 6.20 & 22.36 \\
\hline 130.00 & 40.00 & 4.00 & 14.64 \\
\hline 130.00 & 40.00 & 6.20 & 29.30 \\
\hline 150.00 & 20.00 & 4.00 & 22.31 \\
\hline 150.00 & 20.00 & 6.20 & 32.83 \\
\hline 150.00 & 40.00 & 4.00 & 24.96 \\
\hline 150.00 & 40.00 & 6.20 & 15.23 \\
\hline 123.18 & 30.00 & 5.10 & 33.93 \\
\hline 156.82 & 30.00 & 5.10 & 21.54 \\
\hline 140.00 & 13.18 & 5.10 & \\
\hline
\end{tabular}


RASĀYAN J. Chem.

Vol. 11 | No. 4 |1564 - 1571| October - December | 2018

\begin{tabular}{l|l|l|l}
\hline 140.00 & 46.82 & 5.10 & 20.91 \\
\hline 140.00 & 30.00 & 3.25 & 26.42 \\
\hline 140.00 & 30.00 & 6.95 & 22.74 \\
\hline 140.00 & 30.00 & 5.10 & 24.75 \\
\hline 140.00 & 30.00 & 5.10 & 24.70 \\
\hline
\end{tabular}

The effect of the variables on the response is investigated using a second-order polynomial regression equation. Meanwhile, the effect estimation was shown in Table 4. Equation 1 represents the effect of temperature $\left(\mathrm{X}_{1}\right)$. extraction time $\left(\mathrm{X}_{2}\right)$. and solvent volume $\left(\mathrm{X}_{3}\right)$ towards the curcumin concentration $(\mathrm{y})$ of the pressurized liquid water extraction.

$\mathrm{Y}=24.77+9.88 \mathrm{X}_{1}-0.36 \mathrm{X}_{1}^{2}-0.32 \mathrm{X}_{2}-2.73 \mathrm{X}_{2}^{2}-1.90 \mathrm{X}_{3}-0.35 \mathrm{X}_{3}^{2}+3.41 \mathrm{X}_{1} \mathrm{X}_{2}-5.70 \mathrm{X}_{1} \mathrm{X}_{3}-0.40 \mathrm{X}_{2} \mathrm{X}_{3}$

A regression model of the pressurized liquid water of curcumin showed that temperature $\left(\mathrm{X}_{1}\right)$ and interaction of temperature and extraction time $\left(\mathrm{X}_{1} \mathrm{X}_{2}\right)$ had a positive effect towards the curcumin concentration. Meanwhile extraction time $\left(\mathrm{X}_{2}\right)$. and solvent volume $\left(\mathrm{X}_{3}\right)$ had a negative effect. A negative effect was also shown by all the guadratic term and so the combination effect of temperature-solvent volume $\left(\mathrm{X}_{1} \mathrm{X}_{3}\right)$ and extraction time-solvent volume $\left(\mathrm{X}_{2} \mathrm{X}_{3}\right)$. The positive effect of temperature on the extraction of curcumin was also reported ${ }^{11}$. The curcumin was extracted by ethanol in a soxhletation.

Table-4: The Effect Estimation of the Pressurized Liquid Water Extraction of Curcumin

\begin{tabular}{|c|c|c|c|c|c|c|c|c|c|c|}
\hline \multirow[b]{2}{*}{ Factor } & \multicolumn{10}{|c|}{$\begin{array}{l}\text { Effect Estimates; Var.:Qurcumin Concentration (\%w); R-sqr=.98947; Adj:.97368 (Spreadsheet1) } \\
3 \text { factors, } 1 \text { Blocks, } 16 \text { Runs; MS Residual=.8071086 } \\
\text { DV: Curcumin Concentration (\%w) }\end{array}$} \\
\hline & Effect & Std.Err. & $\mathrm{t}(6)$ & $p$ & $\begin{array}{c}-95 . \% \\
\text { Onf.Limt }\end{array}$ & $\begin{array}{c}+95 . \% \\
\text { Cnf.Limt }\end{array}$ & Coeff. & $\begin{array}{l}\text { Std.Err. } \\
\text { Coeff. }\end{array}$ & $\begin{array}{c}-95 . \% \\
\text { Cnf.Limt }\end{array}$ & $\begin{array}{c}+95 . \% \\
\text { Cnf.Limt }\end{array}$ \\
\hline Mean/Interc. & 24.77802 & 0.633397 & 39.11923 & 0.000000 & 23.22815 & 26.32789 & 24.77802 & 0.633397 & 23.22815 & 26.32789 \\
\hline (1)Temperature $(\mathrm{oC})(\mathrm{L})$ & 9.88612 & 0.486206 & 20.33317 & 0.000001 & 8.69641 & 11.07582 & 4.94306 & 0.243103 & 4.34821 & 5.53791 \\
\hline Temperature $(\mathrm{oC})(\mathrm{Q})$ & -0.36136 & 0.590328 & -0.61213 & 0.562917 & -1.80584 & 1.08313 & -0.18068 & 0.295164 & -0.90292 & 0.54156 \\
\hline (2) Time (Minutes) $(\mathrm{L})$ & -0.32774 & 0.486206 & -0.67408 & 0.525367 & -1.51744 & 0.86196 & -0.16387 & 0.243103 & -0.75872 & 0.43098 \\
\hline Time (Minutes)(Q) & -2.73302 & 0.590328 & -4.62966 & 0.003579 & -4.17750 & -1.28854 & -1.36651 & 0.295164 & -2.08875 & -0.64427 \\
\hline (3)Volume $(L)(L)$ & -1.90160 & 0.486206 & -3.91111 & 0.007882 & -3.09131 & $-0.7119 d$ & -0.95080 & 0.243103 & -1.54565 & -0.35595 \\
\hline Volume $(L)(Q)$ & -0.35837 & 0.590328 & -0.60707 & 0.566051 & -1.80285 & 1.08611 & -0.17919 & 0.295164 & -0.90143 & 0.54305 \\
\hline $1 \mathrm{~L}$ by $2 \mathrm{~L}$ & 3.41472 & 0.635259 & 5.37532 & 0.001703 & 1.86030 & 4.96914 & 1.70736 & 0.317630 & 0.93015 & 2.48457 \\
\hline $1 \mathrm{~L}$ by $3 \mathrm{~L}$ & -5.70600 & 0.635259 & -8.98215 & 0.000106 & -7.26042 & -4.15157 & -2.85300 & 0.317630 & -3.63021 & -2.07579 \\
\hline $2 \mathrm{~L}$ by $3 \mathrm{~L}$ & -0.40460 & 0.635259 & -0.63690 & 0.547707 & -1.95902 & 1.14983 & -0.20230 & 0.317630 & -0.97951 & 0.57491 \\
\hline
\end{tabular}

The graphical representation of their function was called response surface. which is used to describe the individual and cumulative effect of the test variables and their subsequent effect on the response.

The response surface was expressed at the following second-order polynomial equation:

$Y=24.77+9.88 X_{1}-0.36 X_{1} X_{1}-0.32 X_{2}-2.73 X_{2} X_{2}-1.90 X_{3}-0.35 X_{3} X_{3}+3.41 X_{1} X_{2}-5.70 X_{1} X_{3}-0.4$ $\mathrm{X}_{2} \mathrm{X}_{3}$

Where $y$ is the response (curcumin concentration) and $\mathrm{X}_{1} . \mathrm{X}_{2}$. and $\mathrm{X}_{3}$ are representing the temperature $\left({ }^{\circ} \mathrm{C}\right)$. extraction time (minutes). and solvent volume (L). respectively.

The quality of the model developed was evaluated based on the correlation coefficient $R^{2}$. The $R^{2}$ for the obtained equations were found to be 0.989 (Table-4). The value of $\mathrm{R}^{2} 0.989$ indicated that $989 \%$ of total variation in the pressurized liquid water extraction were attributed to the experimental variables studied. The value $\mathrm{R}^{2}$ of 0.989 is considered as the good fit of the model. Generally. it is stated that $\mathrm{R}^{2}$ higher than 0.90 is considered as the indication of the model high correlation ${ }^{12}$. The p-values of the parameters studies were mostly less than 0.01 (Table-4). It indicates that the model we adequate to predict the pressurized liquid water extraction of curcumin in the range of the variables studied in this research. Table 4 showed that temperature $(\mathrm{L})$. extraction time $(\mathrm{Q})$. volume $(\mathrm{L})$ are significantly influence the pressurized liquid water of curcumin. since their p-value is less than 0.05 . 
RASĀYAN J. Chem.

Vol. 11 | No. 4 |1564 - 1571| October - December | 2018

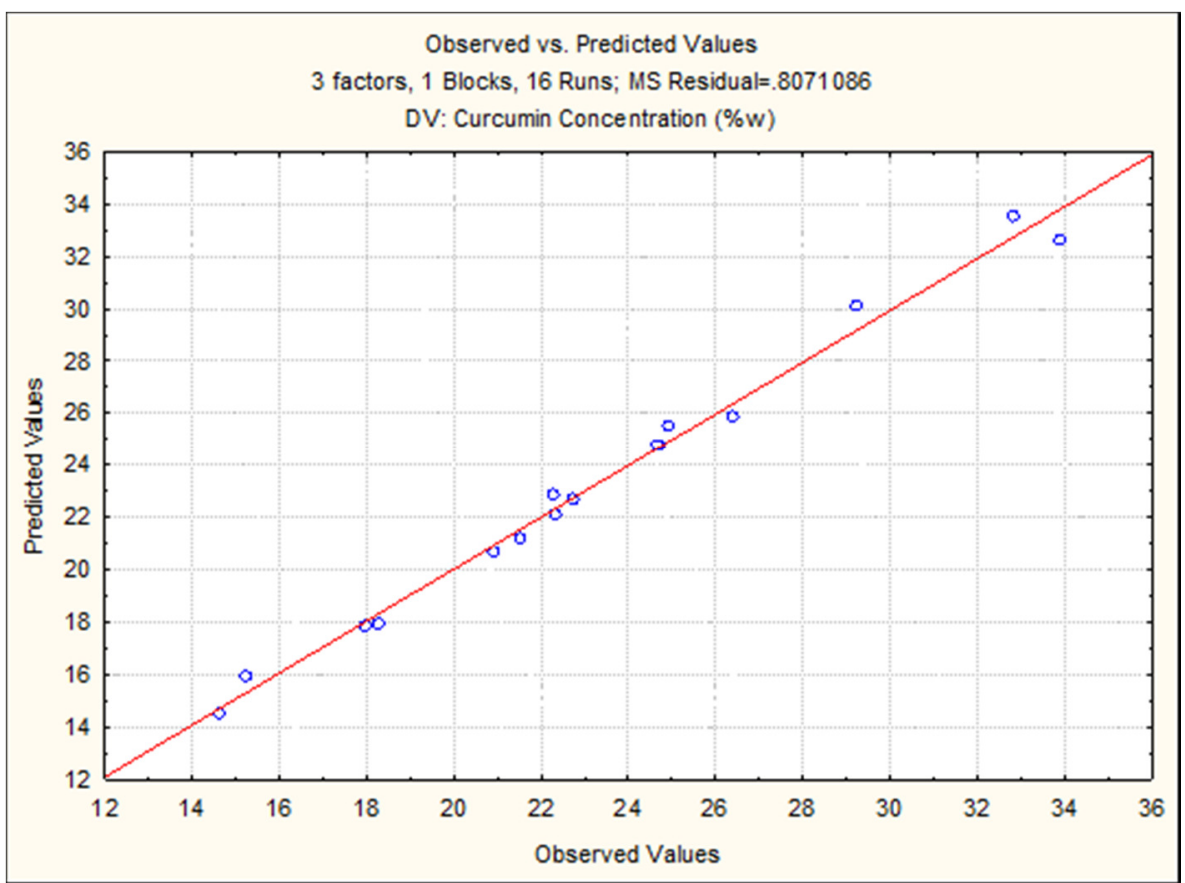

Fig.-1: The Observed vs Predicted Values

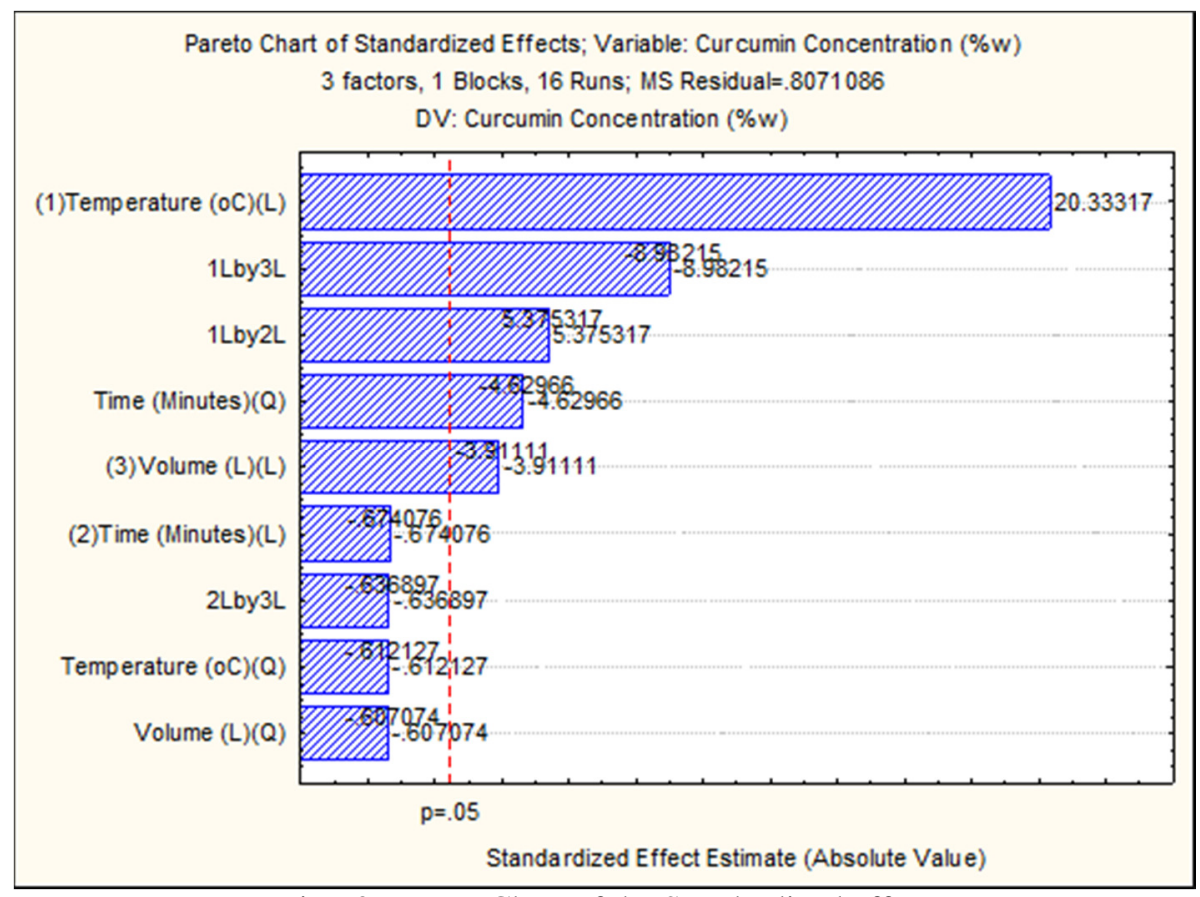

Fig. -2: Pareto Chart of the Standardized effect

The closeness of the model and the experimental data is shown on the observed and predicted values as depicted on Fig.-1. Furthermore. Fig.-2. ilustrated the pareto chart of the Standardized effect. It showed that temperature was the most influencing variable of the pressurized liquid water extraction of curcumin. The dominant influence of temperature on the curcumin extraction was also mentioned in the optimization process by using Box Behnken Design ${ }^{11}$. Temperature. followed by a quadratic term of time. quadratic term 
RASĀYAN J. Chem.

Vol. 11 | No. 4 |1564 - 1571| October - December | 2018

of temperature was the major process parameters that influence the soxhletation of curccumin from turmeric powder ${ }^{11}$.

Response surface contour plots of the RSM on the effect of solvent volume. time and temperature on the curcumin concentration are shown in Figures- 3 to 5.

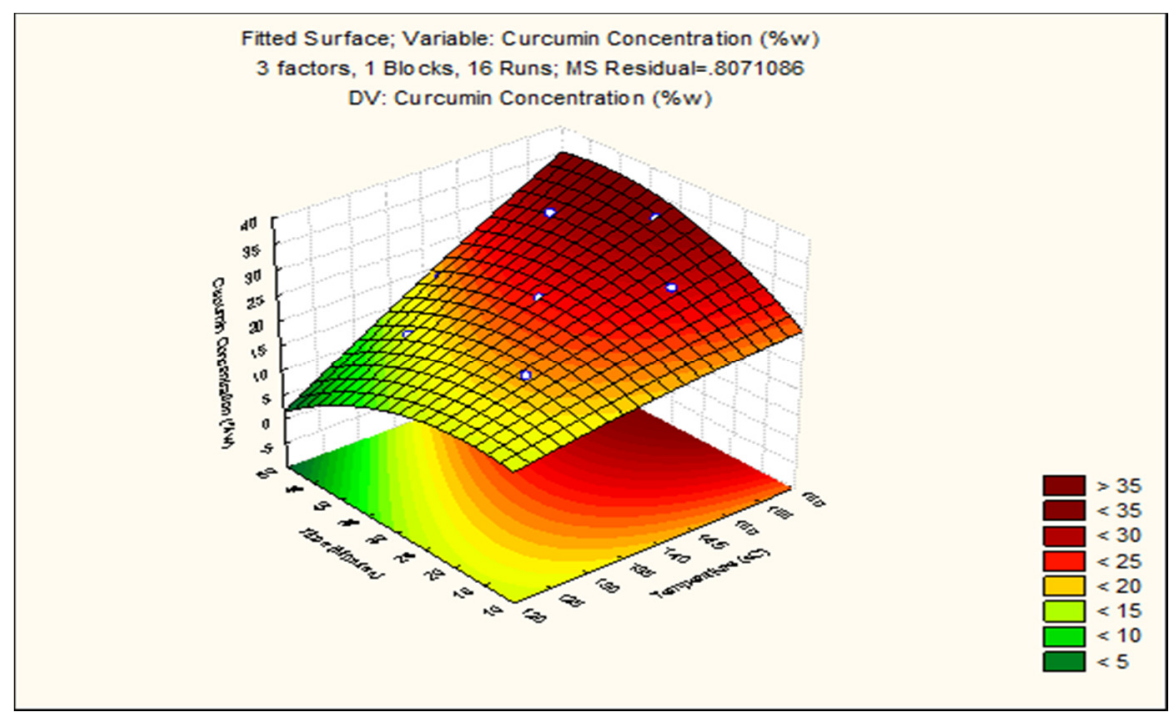

Fig. -3: The response surface contour plots of the RSM on the effect of temperature and time on the curcumin concentration

Figure-3 showed that showed that increasing temperature and time of the extraction could increase the curcumin concentration. The response surface plot indicates that optimized condition at 25 minutes and temperature of $150^{\circ} \mathrm{C}$ gave $>35 \%$ of the curcumin concentration yield in the pressurized liquid extraction. The curcumin concentration obtained by the pressurized liquid water extraction was much higher than the curcumin concentration obtained by the conventional extraction method. Soxhletation of turmeric powder by using ethanol only gave a curcumin concentration as high as $4.1 \%{ }^{11}$. Meanwhile, curcumin concentration as high as $12.89 \%$ was obtained by ethanol extraction at a temperature of $60^{0}$ for 30 minutes $^{13}$.

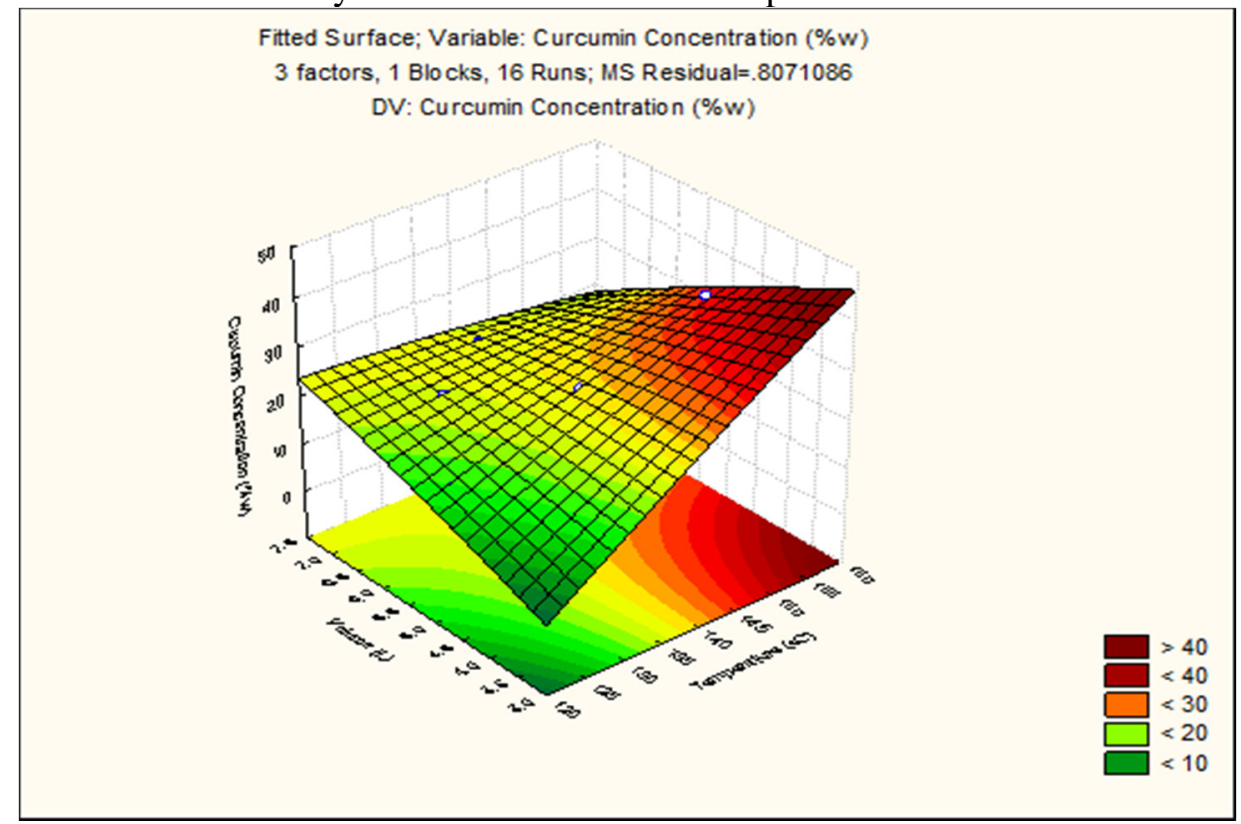

Fig -4. The response surface contour plots of the RSM on the effect of temperature and solvent volume on the curcumin concentration 
Fig -4 showed that increasing temperature while maintained the low level of solvent volume could increase the curcumin concentration. Response surface plot indicates that optimized condition at $4 \mathrm{~L}$ of the solvent volume and temperature of $150^{\circ} \mathrm{C}$ gave $>40 \%$ of the curcumin concentration yield in the pressurized liquid extraction.

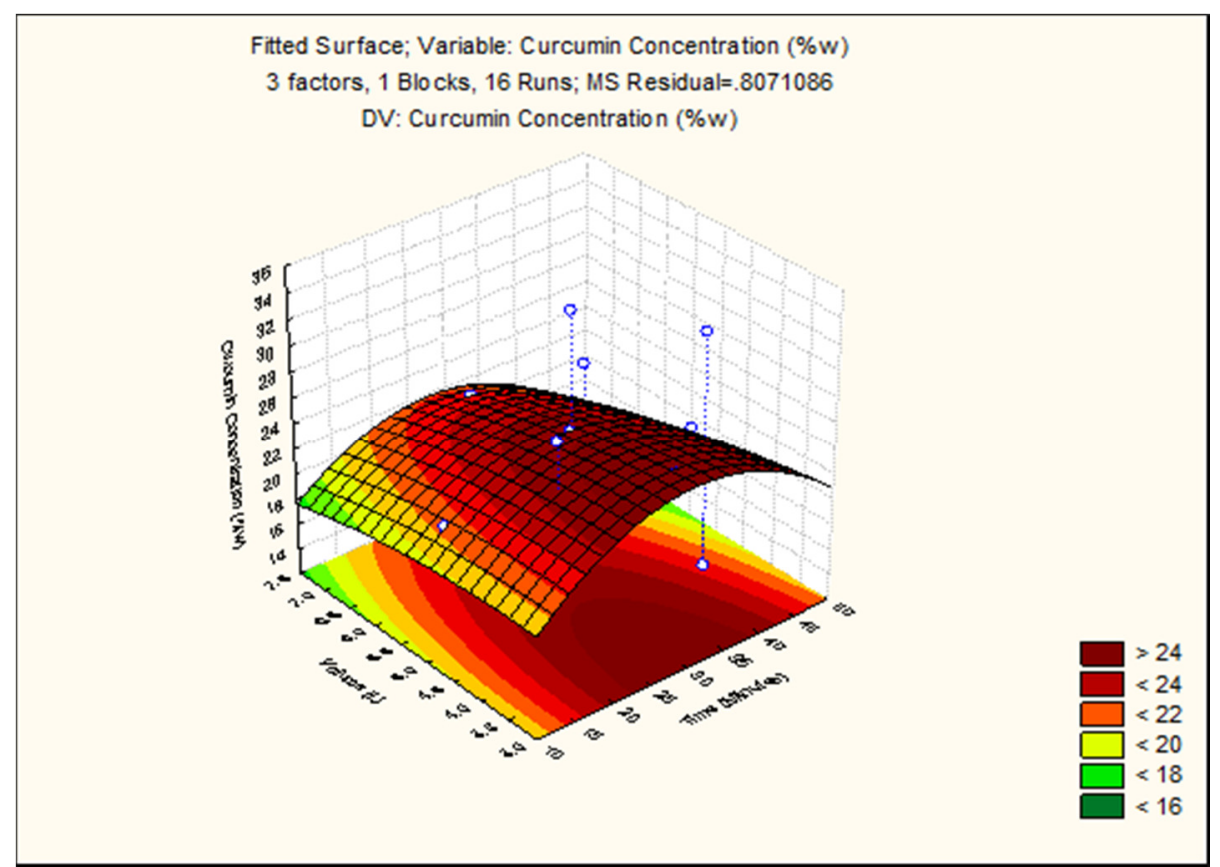

Fig.-5: The response surface contour plots of the RSM on the effect of solvent volume and time on the curcumin concentration

Figure- 4 showed that increasing time while maintained the low level of solvent volume could increase the curcumin concentration. Response surface plot indicates that optimized condition at $4 \mathrm{~L}$ of the 25 minutes of extraction and volume of $2.35 \mathrm{~L}$ gave $>24 \%$ of the curcumin concentration yield in the pressurized liquid extraction. The optimal value of the pressurized liquid water extraction of curcumin was obtained by solving the second-order polynomial regression equation. The optimal condition of the pressurized liquid water extraction of curcumin was the temperature of $156.81^{\circ}$. an extraction time of 46.81 minutes and solvent volume of $6.95 \mathrm{~L}$.

\section{CONCLUSION}

The research showed that the model was adequate to predict the pressurized liquid water extraction of curcumin in the range of the variables studied in this research. The research showed that temperature was the most influencing variable for the pressurized liquid water extraction of curcumin from Curcuma domestica Val. The response surface contour plots of the RSM on the effect of solvent volume. time and temperature on the curcumin concentration have shown that the optimum condition for pressurized liquid water extraction of curcumin was extraction performed at a temperature of 156 . and mid-level of extraction temperature.

\section{REFERENCES}

1. X. Liang, Q. Fan, J. Mater. Sci. Chem. Eng.,, 1, 5 (2013), DOI: 10.4236/msce.2013.15001

2. S. Tunchaiyaphum, M. N. Eshtiaghi, N.Yoswathan, Int. J. Chem. Eng. Appl., 4, 4 (2013), DOI: 10.7763/IJCEA.2013.V4.293

3. M. E. Yulianto, P. Kusumo, I. Hartati, Wahyuningsih, Rasayan J. Chem., 10, 3(2017), DOI: $10.7324 /$ RJC.2017.1031619

4. A. Sharifi, S. A. Mortazavi, A. Maskooki, M. Niakousari, A. H. Elhamirad, Int. J. Agric., 6, 2 (2013)

5. S. Li. W. Yuan. P.Yang. M.D. Antoun. M.J. Balick. G.M. Cragg. Pharm. Crops., 1, 1 (2010), DOI: $10.2174 / 2210290601001010001$

6. N. Kertia. A.H. Asdie. W. Rochmah. and Marsetyawan. J. Pharmacognosy Phytother., 4, 5(2012), DOI: $10.5897 /$ JPP11.079 
RASĀYAN J. Chem.

Vol. 11 | No. 4 |1564 - 1571| October - December | 2018

7. S.S. Than. Chem Eng Trans, 56 (2017), DOI: 10.3303/CET1756270

8. A. Ma'rufm, B. Pramudono, N. Aryanti, Rasayan J. Chem., 10, 2(2017), DOI: $10.7324 /$ RJC.2017.1021667

9. G. Nandhavathy, S. Periyar Selvam, M. Mahesh Kumar, E. Rotimi Sadiku, Rasayan J. Chem., 10, 2 (2017), DOI: 10.7324/RJC.2017.1021724

10. W.M. Mumtaz, A. Adnan, F. Anwar, H. Mukhtar, M. A. Raza, F. Ahmad, U. Rashid, Energies., 5 (2012), DOI: 10.3390/en5093307

11. A. Avram. M. Stroescu. A. Stoica-Guzun. O. Floarea. T. Dobre. Rev. Chim., 66, 1(2015)

12. S. Wang. T. You. F. Xu. J Chen. and G. Yang. Bioresources., 10, 4 (2015)

13. D. S. Sogi. S. Sharma. D. P. S. Oberoi. and I. A. Wani. J. Food Sci. Technol., 47, 3(2010), DOI:10.1007/s13197-010-0047-8

[RJC-1990/2017] 